
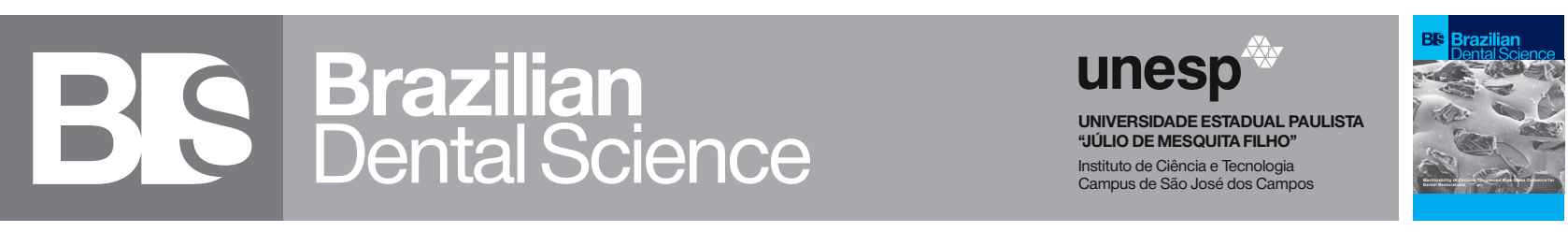

\title{
Prevalence of Gingival Hyperplasia Induced by Anticonvulsants: A Systematic Review
}

\author{
Prevalência da Hiperplasia Gengival Induzida pelo uso de anticonvulsivantes: Revisão sistemática
}

\begin{abstract}
Marina Módolo CLÁUDIO ${ }^{1}$, João Victor Soares RODRIGUES ${ }^{1}$, Valdir Gouveia GARCIA ${ }^{2}$, Leticia Helena THEODORO ${ }^{3}$
1 - São Paulo State University (UNESP), School of Dentistry, Araçatuba, Department of Diagnostic and Surgery, Division of Periodontology, Araçatuba, SP, Brazil.

2 - Latin American Institute of Dental Research and Education (ILAPEO), Curitiba, PR, Brazil.

3 - Dental Assistance Center for Disabled Persons (CAOE), Department of Diagnostic and Surgery, Division of Periodontology, São Paulo State University (UNESP), School of Dentistry, Araçatuba, SP, Brazil.
\end{abstract}

\begin{abstract}
Objective: Gingival hyperplasia $(\mathrm{GH})$ is one of the side effects of anticonvulsant drugs. The aim of this study was to verify the prevalence of $\mathrm{GH}$ associated with the use of anticonvulsant, through a systematic review. Material and Methods: Systematic search was done at databases Pubmed and Embase between January 1984 and March of 2020 for identification of articles addressing the prevalence of $\mathrm{GH}$ associated with the use of anticonvulsant drugs. The methodological index for non-randomized studies (MINORS) was independently assessed for quality in the selected papers. Results: The search identified 4.471 references. Nine articles were selected and evaluated 632 participants. All of the studies included in the systematic review showed a low risk of bias. The anticonvulsants used by patients were carbamazepine, ethosuximide, phenytoin, primidone, phenobarbital, sodium valproate. The studies showed a correlation between different types of anticonvulsants and $\mathrm{GH}$ prevalence, with a range from $0 \%$ to $73 \%$. Among the anticonvulsants used, phenytoin showed the greatest incidence of $\mathrm{GH}$, varying between $15.61 \%$ and $73 \%$ in patients. Conclusion: In the analysis of the results obtained in the literature, it is possible to notice that the great majority of studies presented incidence of GH associated with anticonvulsant use. However, further studies are necessary to understand the anticonvulsant action mechanism inducing $\mathrm{GH}$, as well as the prevention forms, given that $\mathrm{GH}$ is a significant side effect.
\end{abstract}

\section{KEYWORDS}

Anticonvulsants; Gingival hyperplasia; Prevalence.

\section{RESUMO}

Objetivo: Hiperplasia gengival (HG) é um dos efeitos colaterais das drogas anticonvulsivantes. O objetivo deste estudo foi verificar a prevalência de HG associada ao uso de anticonvulsivantes, por meio de uma revisão sistemática. Material e Métodos: A busca sistemática foi realizada nas bases de dados Pubmed e Embase entre janeiro de 1984 e março de 2020 para identificação de artigos que abordassem a prevalência de HG associada ao uso de drogas anticonvulsivantes. Foi avaliado independentemente, o risco de viés através do "Methodological index for non-randomized studies" (MINORS), para análise da qualidade dos trabalhos selecionados. Resultados: A pesquisa identificou 4.471 referências. Nove artigos foram selecionados e avaliaram 632 participantes. Todos os estudos incluídos na revisão sistemática mostraram baixo risco de viés. Os anticonvulsivantes utilizados pelos pacientes foram carbamazepina, etossuximida, fenitoína, primidona, fenobarbital e valproato de sódio. Os estudos mostraram correlação entre os diferentes tipos de anticonvulsivantes e a prevalência de HG, com variação entre $0 \%$ a $73 \%$. Entre os anticonvulsivantes utilizados, a fenitoína apresentou a maior incidência de $H G$, variando entre $15,61 \%$ e $73 \%$ em pacientes. Conclusão: $\mathrm{Na}$ análise dos resultados obtidos na literatura, é possível notar que a grande maioria dos estudos apresentou incidência de HG associada ao uso de anticonvulsivantes. No entanto, estudos adicionais são necessários para compreender o mecanismo de ação do anticonvulsivante para a indução da HG, bem como as formas de prevenção, dado que a HG é um efeito colateral significativo.

\section{PALAVRAS-CHAVE}

Anticonvulsivantes; Hiperplasia gengival; Prevalência. 


\section{INTRODUCTION}

G ingival hyperplasia (GH) is a common condition to patients who take three different drug classes, anticonvulsants (phenytoin, phenobarbital, vigabatrin), immunosuppressors (cyclosporine A) and calcium channel blockers (nifedipine, amlodipine, diltiazem, verapamil) [1-5]. The pathogenesis of this condition is multifactorial, involving a number of factors, including the quality of plaque control, gingival inflammation, age, sex, duration of therapy, drug concentration, concomitant use of certain medications and genetic factors [4].

Epilepsy is a very frequent neurological disease, surpassed in number only by cerebrovascular accident. Its incidence significantly varies with age, affecting nearly $1 \%$ of the population worldwide. Epilepsy is a condition that requires the use of anticonvulsants, and phenytoin (PHE) is the most frequently prescribed drug, as it is clinically effective, powerful and inexpensive [2,6-7]. PHE was initially adopted in 1938 and the first case reported in the literature on GH associated with the use of PHE was in 1939, by Kimball [8]. Since then, there has been a growing number of studies on this subject [9].

GH may develop within 1 to 3 months after the beginning of an anticonvulsant treatment. Initially, this hyperplasia is present in the interdental papilla and shows a diffuse increase, extending to the free gingiva and attached gingiva, exhibiting a lobulated aspect $[4,10-12]$. It mainly affects the anterior region, both in the maxilla and mandible [2]. At times, this proliferative tissue may cover the teeth vestibular face, leading to dental displacement [10], besides unfavorable esthetics and difficult teeth cleaning. GH can reach occlusal and lingual faces, interfering in speech, mastication and occlusion. Finally, GH induces plaque accumulation, increasing the susceptibility to periodontal disease and cavities [1].

Although PHE is the main used and studied anticonvulsant, several others are also associated with GH during therapy, including carbamazepine (CBZ) [10,13-14], sodium valproate (VPT) [14-15], primidone (PMD) [10], phenobarbital (PB) $[6,10]$, vigabatrin (VGB) [16]. This systematic review was performed aiming at verifying, in the literature, the prevalence of GH associated with anticonvulsant use, due to great da ta variability and the importance of awareness on this issue. These data are important in order to plan preventive actions and better kinds of treatment for $\mathrm{GH}$, improving buccal health conditions and patient quality of life. Therefore, integrated knowledge on this side effect of the therapy with anticonvulsant is fundamental for dental practice.

\section{MATERIAL AND METHODS}

\section{Focus issue}

The present systematic review was carried out in agreement with the Cochrane Collaboration and followed the principles of Preferred Reporting Items for Systematic Reviews and Meta-analysis [17]. Questions raised in this study were developed using patient characteristics, type of intervention, control, and outcome (PICO). The focus questions analyzed in this review were the following: "What is the prevalence of gingival hyperplasia associated with anticonvulsant use?" and "Which anticonvulsant develops higher incidence of gingival hyperplasia?"

\section{Search strategy}

Two databases (PubMed and EMBASE) were systematically analyzed between January 1984 and March of 2020 for selection of articles. The keywords used in the searches were ("phenytoin" [MeSH Terms] or "phenytoin" [All Fields]) and ("gingival overgrowth" [MeSH Terms] or ("gingival" [All Fields] and "overgrowth" [All Fields]) or "gingival overgrowth" [All Fields]); ("phenytoin" [MeSH Terms] or "phenytoin" [All Fields]) and ("gingival hyperplasia" [MeSH Terms] or ("gingival" [All Fields] and "hyperplasia" [All Fields]) or "gingival hyperplasia" [All Fields]); ("anticonvulsants" [Pharmacological Action] or "anticonvulsants" [MeSH Terms] or "anticonvulsants" [All Fields]) and ("gingival overgrowth" [MeSH Terms] or ("gingival" [All Fields] and "overgrowth" [All Fields]) or "gingival overgrowth" [All Fields]); ("anticonvulsants" [Pharmacological Action] or "anticonvulsants" [MeSH Terms] or "anticonvulsants" [All Fields]) and ("gingival hyperplasia" [MeSH Terms] or ("gingival" [All Fields] and "hyperplasia" [All Fields]) or "gingival hyperplasia" [All Fields].

\section{Selection of articles}

The selection criteria of articles were: a) controlled clinical studies; b) retrospective and prospective studies: c) studies evaluating the prevalence of gingival hyperplasia associated with anticonvulsant use. The exclusion criteria were the following: literature reviews, clinical case reports, case series and studies not published in the English language. 


\section{Data collection}

A reviewer (MC) collected the main data in the articles and two reviewers (MC and JVS) did the analysis of the studies. In case of doubt, a third reviewer (LT) was consulted. The following data were collected from the selected studies: year of publication, country, authors, study design, prevalence of GH, number of participants, and period of evaluation. Only data on the prevalence of $\mathrm{GH}$ presented by the authors as tables or in the text were considered.

\section{Analysis of bias}

The methodological index for non-randomized studies (MINORS) was independently assessed for quality in the selected papers (Table I) [18]. The items are scored 0 (not reported), 1 (reported but inadequate) or 2 (reported and adequate), being the global ideal score 16 for non-comparative studies and 24 for comparative studies.

\section{RESULTS}

\section{Result of the search and excluded studies}

The electronic database searches using EMBASE and PubMed are shown in the flowchart (Figure 1). Nine articles were selected after abstract analysis by two reviewers (MC and JVS), considering the prevalence of $\mathrm{GH}$ in patients under anticonvulsant treatment.

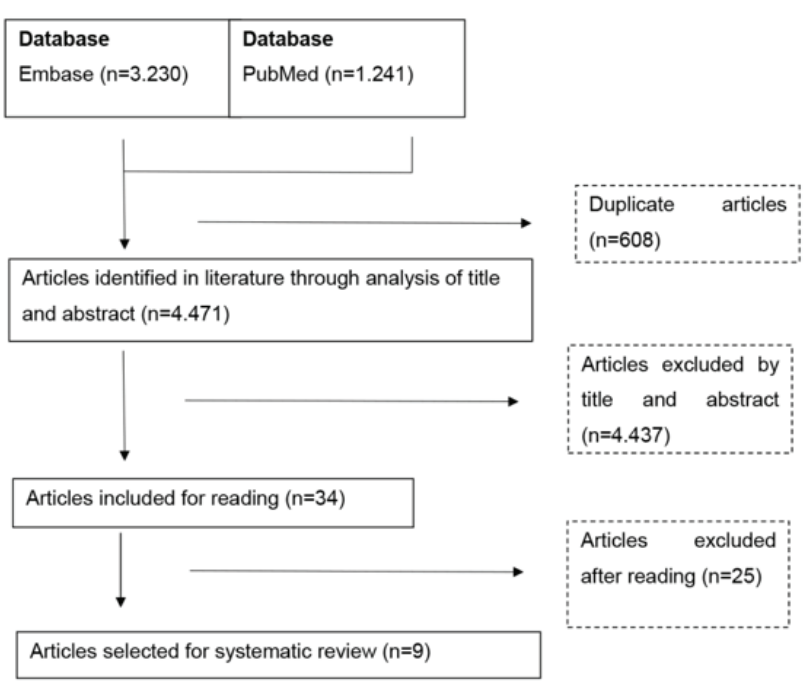

Figure 1 - Flow diagram of the search strategy.

\section{Description of studies}

Among the nine analyzed studies (Table II), Suneja et al. (2016) [14] evaluated anticonvulsant effects on GH and the factors that influence its development by analyzing 30 children divided in three groups, according to the monotherapy in use, which could include PHE, VPT and CBZ. During a 6-month follow-up period, 53.6\% prevalence of GH was observed in patients using PHE in the first 3 months of evaluation. VPT also presented GH, but at a mild level, showing no statistical relevance; while CBZ showed no signs of GH.

In a prospective observational study, Prasad et al. (2002) [7] also verified the prevalence of GH associated with PHE, during a six-month follow-up period in children. Thirty children were evaluated, and $57 \%$ presented GH in the mesiodistal area, reaching up to $82.35 \%$ in the vestibular area after 6 months of anticonvulsant use.

In a cross-sectional study, Brunet et al. (2001) [5] evaluated the prevalence of GH with two indices and the risk factors for its development. In that study, PHE action was evaluated in association or not with PB. Higher GH index was noticed in patients taking PHE (73\%) compared with PB (31.8\%) and control (1\%) groups. In addition, when severity was evaluated, PHE presented $16.2 \%$ of cases, while PB was associated with $4.5 \%$.

Majola et al. (2000) [19] analyzed the prevalence and severity of GH associated with PHE and its relationship with the risk factors. One hundred and thirtyfour patients (average age: 32 years) making exclusive use of PHE or its association with another anticonvulsant were selected. Among those patients, $62 \%$ presented GH. Additional laboratorial tests showed that PHE and serum folate concentrations were $0.03 \mathrm{mg} / 1$ to $3.89 \mathrm{mg} / 1$ and $1.2 \mathrm{ng} / \mathrm{ml}$ to $14.7 \mathrm{ng} / \mathrm{ml}$, respectively. A great number of patients (77\%) reported brushing teeth regularly, while $3 \%$ admitted to not brushing.

Kamali et al. (1999) [10] evaluated the incidence of GH and the effects of co-medication of other anticonvulsants associated with PHE, monitoring anticonvulsant levels in the saliva and plasma. Thirtysix patients making use of PHE for at least 6 months without dosage alteration were selected. Out of these, 13 patients also made use of another medication such as CBZ (9), PB (3) and PMD (1). The age average of the patients was approximately 39.5 years for those taking only PHE and 38.8 for those associating 
PHE. The prevalence of $\mathrm{GH}$ was $57 \%$ for patients under monotherapy with PHE and 31\% in patients associating PHE with CBZ, PB or PMD.

Perlík et al. (1995) [20] studied PHE concentration in the plasma of adult patients (average age: $36.55 \pm 10.24$ years), taking the drug for at least 1 year. This study evaluated 54 patients (27 women; 27 men) with epilepsy under anticonvulsant treatment, out of which 22 were under PHE monotherapy and 32 under polytherapy using VPT, CBZ, PMD, PB, ethosuximide or clonazepam. Among the analyzed patients, $24 \%$ presented mild to severe $\mathrm{GH}$. In women, at least $55.5 \%$ discrete alterations or no hyperplasia were found, whereas approximately $77.7 \%$ of the men presented mild and/or severe GH. The obtained data demonstrated that the higher the dosage and the longer the use of PHE therapy, associated or not with another drug, the higher the incidence of GH.

Dahllof et al. (1993) [13] compared the periodontal condition of adult patients treated longterm with PHE or CBZ. Forty adult patients were selected (average age: 51 years) and treated with anticonvulsant therapy for 18 years on average (1031 years). Regarding the drug type, 18 individuals were under PHE monotherapy, 11 were receiving an association between PHE and another type of anticonvulsant, 10 were receiving CBZ monotherapy and one was under CBZ associated with PB treatment.
It was observed that $35 \%$ of patients taking PHE developed GH grade 1, while only $10 \%$ of patients using CBZ showed GH grade 1 .

Thomason et al. (1992) [21] compared the incidence of GH associated with the use of PHE in epileptic patients with gingival alterations typical of healthy patients. The percentage of GH found in these patients was $13 \%$, which is considered low compared with other studies. In this study, a correlation between bacterial plaque and $\mathrm{GH}$ indices was also demonstrated, however, it was not possible to associate GH with drug concentration in the saliva.

Seymour et al. (1985) [15] analyzed the periodontal health of 45 adult epileptic patients, under PHE (average age: 34.2 years) or SV (average age: 31.3 years) monotherapies, besides control patients (average age: 35 years) who were not making use of anticonvulsant. These patients were under anticonvulsant treatment for no less than 2 years and 4 years maximum. GH was more significant in patients making use of PHE (34.5\%), compared with SV and control groups (18\%).

\section{Risk of Bias}

All of the studies [5,7,10,13-15,19-21] included in the systematic review showed a low risk of bias, with score varying from 16 to 24 (good quality; Table I). There was no disagreement between the reviewers assessing and evaluating the quality of studies.

Table I - Quality assessment of the selected studies (MINORS)

\begin{tabular}{|c|c|c|c|c|c|c|c|c|c|}
\hline Quality criteria & $\begin{array}{l}\text { Seymour et } \\
\text { al.1985 }\end{array}$ & $\begin{array}{l}\text { Thomason } \\
\text { et al.1992 }\end{array}$ & $\begin{array}{l}\text { Dahllöf et } \\
\text { al.1993 }\end{array}$ & $\begin{array}{l}\text { Perlík et } \\
\text { al.1995 }\end{array}$ & $\begin{array}{l}\text { Kamali et } \\
\text { al.1999 }\end{array}$ & $\begin{array}{l}\text { Majola et } \\
\text { al.2000 }\end{array}$ & $\begin{array}{l}\text { Brunet et } \\
\text { al.2001 }\end{array}$ & $\begin{array}{l}\text { Prasad et } \\
\text { al.2002 }\end{array}$ & $\begin{array}{l}\text { Suneja et } \\
\text { al.2016 }\end{array}$ \\
\hline 1. A clearly stated aim & 2 & 2 & 2 & 2 & 2 & 2 & 2 & 2 & 2 \\
\hline $\begin{array}{l}\text { 2. Inclusion of consecutive } \\
\text { patients }\end{array}$ & 2 & 2 & 2 & 2 & 2 & 2 & 2 & 2 & 2 \\
\hline 3. Prospective collection of data & 2 & 2 & 2 & 2 & 2 & 2 & 2 & 2 & 2 \\
\hline $\begin{array}{l}\text { 4. Endpoints appropriate to the } \\
\text { aim of the study }\end{array}$ & 2 & 2 & 2 & 2 & 2 & 2 & 2 & 2 & 2 \\
\hline $\begin{array}{l}\text { 5. Unbiased assessment of the } \\
\text { study endpoint }\end{array}$ & 2 & 2 & 0 & 0 & 2 & 2 & 2 & 0 & 2 \\
\hline $\begin{array}{l}\text { 6. Follow-up period appropriate to } \\
\text { the aim of the study }\end{array}$ & 2 & 2 & 2 & 2 & 2 & 2 & 2 & 2 & 2 \\
\hline 7. Loss to follow up less than $5 \%$ & 2 & 2 & 2 & 0 & 2 & 2 & 2 & 2 & 2 \\
\hline $\begin{array}{l}\text { 8.Prospective calculation of the } \\
\text { study size }\end{array}$ & 0 & 2 & 2 & 0 & 0 & 0 & 2 & 0 & 0 \\
\hline 9.An adequate control group & 2 & 2 & 1 & 2 & 2 & 2 & 2 & 2 & 1 \\
\hline 10.Contemporary groups & 2 & 2 & 2 & 2 & 2 & 2 & 2 & 2 & 2 \\
\hline 11.Baseline equivalence of groups & 2 & 2 & 2 & 0 & 2 & 0 & 1 & 2 & 0 \\
\hline 12. Adequate statistical analyses & 2 & 2 & 2 & 2 & 2 & 2 & 2 & 2 & 2 \\
\hline Total Score & 22 & 24 & 21 & 16 & 22 & 20 & 23 & 20 & 19 \\
\hline Quality of study & Good & Good & Good & Good & Good & Good & Good & Good & Good \\
\hline
\end{tabular}


Table II - Main demographic characteristics and results of selected articles

\begin{tabular}{|c|c|c|c|c|c|c|c|c|c|}
\hline Authors & $\begin{array}{c}\text { Seymour et al, } \\
1985\end{array}$ & $\begin{array}{l}\text { Thomasonet } \\
\text { al., } 1992\end{array}$ & $\begin{array}{l}\text { Dahllöf et al., } \\
\quad 1993\end{array}$ & Perlík et al., 1995 & $\begin{array}{l}\text { Kamaliet al, } \\
1999\end{array}$ & $\begin{array}{l}\text { Majola et al., } \\
2000\end{array}$ & Brunetet al.,2001 & $\begin{array}{l}\text { Prasad et al., } \\
2002\end{array}$ & $\begin{array}{l}\text { Sunejaet al, } \\
2016\end{array}$ \\
\hline $\begin{array}{l}\text { Study } \\
\text { type }\end{array}$ & $\begin{array}{l}\text { Cross-sectional } \\
\text { study }\end{array}$ & $\begin{array}{l}\text { Cross-sectio- } \\
\text { nal study }\end{array}$ & $\begin{array}{l}\text { Cross-sectional } \\
\text { study }\end{array}$ & $\begin{array}{l}\text { Cross-sectional } \\
\text { study }\end{array}$ & $\begin{array}{l}\text { Cross-sectio- } \\
\text { nal study }\end{array}$ & $\begin{array}{l}\text { Retrospective } \\
\text { cross- sectio- } \\
\text { nal study }\end{array}$ & $\begin{array}{l}\text { Cross-sectional } \\
\text { study }\end{array}$ & $\begin{array}{l}\text { Prospective } \\
\text { observational } \\
\text { study }\end{array}$ & $\begin{array}{l}\text { Cross-sectional } \\
\text { study }\end{array}$ \\
\hline $\begin{array}{l}\text { Drug in } \\
\text { use }\end{array}$ & PHE and VPT & PHE & $\begin{array}{c}\text { PHE, CBZ } \\
\text { association } \\
\text { PHE+ATC; } \\
\text { CBZ+PBT }\end{array}$ & $\begin{array}{c}\text { PHE or associa- } \\
\text { tion PHE+ATC } \\
\text { (CBZ, VPT,PRM, } \\
\text { PB,ETX) }\end{array}$ & $\begin{array}{l}\text { PHE, PB, PRM, } \\
\text { CBZ }\end{array}$ & $\begin{array}{c}\text { PHE; PHE and } \\
\text { CBZ; PHE and } \\
\text { PB }\end{array}$ & PHE, PB & PHE & PHE, VPT,CBZ \\
\hline $\begin{array}{l}\text { Drug } \\
\text { concen- } \\
\text { tration }\end{array}$ & $\begin{array}{l}\text { PHE: } 300 \text { mg/ } \\
\text { day, VPT:600 } \\
\text { mg/day }\end{array}$ & $\begin{array}{l}1.67 \mathrm{mg} / \mathrm{ml} \\
\text { saliva }\end{array}$ & $\begin{array}{c}\text { not assessed } \\
\text { data }\end{array}$ & $\begin{array}{c}\text { Mean PHE do- } \\
\text { sage: } \\
5.19 \mathrm{mg} / \mathrm{kg} / \text { day } \\
\text { mild GH;5.73mg/ } \\
\text { kg/day severe GH }\end{array}$ & $\begin{array}{l}\text { PHE: } 382.6 \\
\text { mg/day; } \\
\text { PHE+ATC: } \\
369.2 \\
\text { mg/day }\end{array}$ & $\begin{array}{l}11.3 \mathrm{mg} / \mathrm{lin} \text { total } \\
\mathrm{PHE} \text { concen- } \\
\text { tration level }\end{array}$ & PHE:300mg/day & not assessed data & $\begin{array}{l}\text { not assessed } \\
\text { data }\end{array}$ \\
\hline $\begin{array}{l}\text { Time of } \\
\text { use }\end{array}$ & $\begin{array}{l}\text { Introduction of } \\
\text { medication at } \\
\text { beginning of } \\
\text { study and conti- } \\
\text { nuous use for at } \\
\text { least } 2 \text { years. }\end{array}$ & not assessed & $\begin{array}{l}\text { average of } 18 \\
\text { years; PHE:19.2 } \\
\text { years of use; } \\
\text { CBZ 14.5 years }\end{array}$ & over 1year & $\begin{array}{l}\text { PHE: } 12 \text { years; } \\
\text { PHE+ATC: } 18 \\
\text { years }\end{array}$ & $\begin{array}{l}\text { not assessed } \\
\text { data }\end{array}$ & $\begin{array}{l}\text { over } 36 \text { months } \\
\text { of use }\end{array}$ & $\begin{array}{l}\text { First use no longer } \\
\text { than } 2 \text { months } \\
\text { before study } \\
\text { selection }\end{array}$ & $\begin{array}{l}\text { Maximum } 6 \\
\text { months of use }\end{array}$ \\
\hline $\begin{array}{l}\text { Plaque } \\
\text { Index }\end{array}$ & $\begin{array}{c}\text { Score: PHE 1.46; } \\
\text { VS } \\
\text { 1.11; Control } 0.82\end{array}$ & $\begin{array}{l}\text { PHE: } 0.77, \\
\text { Control:0.66 }\end{array}$ & $\begin{array}{c}\text { PHEgroup } \\
52.1 \% ; \text { CBZ } \\
\text { group } 36.1 \%\end{array}$ & not assessed data & $\begin{array}{c}\text { PHE: } 34.9 \%, \\
\text { PHE+ ATC: } \\
21.3 \%\end{array}$ & $\begin{array}{l}31 \% \text { of patients } \\
\text { presented } 1.8 \\
\text { plaque score }\end{array}$ & $\begin{array}{c}\text { Pl>2.5= PHE: } 86,5 \% ; \\
\text { non } \\
\text { PHE: } 90.9 \% \text {; control: } \\
55.1 \%\end{array}$ & $\begin{array}{l}\text { At } 3 \text { months: } 3.42 \\
\text { (score); at } 6 \\
\text { months: } \\
3.97 \text { (score) }\end{array}$ & $\begin{array}{c}\text { PHE: 1.48;VPT: } \\
\text { 1.23; } \\
\text { CBZ: } 1.44\end{array}$ \\
\hline $\begin{array}{l}\text { Number of } \\
\text { patients }\end{array}$ & $\begin{array}{l}45 \text { patients: } 15 \\
\text { PHE, } 15 \\
\text { VPT, } 15 \text { control }\end{array}$ & $\begin{array}{l}46 \text { patients: } \\
23 \text { PHE group, } \\
\text { and } 23 \text { control }\end{array}$ & $\begin{array}{l}40 \text { patients } \\
\text { (PHE:18 patien- } \\
\text { ts; PHE+ATC:11; } \\
\text { CBZ:10;CB- } \\
\text { ZUPB:1) }\end{array}$ & 54 patients & $\begin{array}{l}36 \text { adults: } 23 \\
\text { PHE, } 13 \\
\text { nonPHE }(9 \\
\text { CBZ,3PB, } \\
\text { 1PRD) }\end{array}$ & 134 patients & $\begin{array}{l}157 \text { patients: ATC } \\
\text { group:59 } \\
\text { [PHE: } 37 \text { and } \\
\text { nonPHE 22]; } \\
\text { control group: } 98\end{array}$ & 30 patients & $\begin{array}{c}90 \text { patients: } 30 \\
\text { patients per } \\
\text { group, } 3 \text { groups }\end{array}$ \\
\hline Female & 22 & 27 & 21 & 27 & 19 & 23 & 42 & - & 39 \\
\hline Male & 23 & 19 & 19 & 27 & 17 & 111 & 54 & - & 51 \\
\hline Age & $\begin{array}{c}\text { PHE } 34.2 \text { years; } \\
\text { VTP } \\
\text { 31.3 years; con- } \\
\text { trol } 35 \text { years }\end{array}$ & $\begin{array}{l}\text { PHE: } 40 \text { years; } \\
\text { control: } 50 \\
\text { years }\end{array}$ & 51 years (43-61) & 35,48 years old & $\begin{array}{c}\text { PHE: } 39.5 \text { year; } \\
\text { PHE } \\
\text { +AED: } 38.8 \\
\text { years }\end{array}$ & $\begin{array}{l}\text { average: } 33.6 \\
\text { years }\end{array}$ & $\begin{array}{c}\text { PHE: } 35.18 \text { years; } \\
\text { nonPHE } \\
\text { 24.27 years; control: } \\
46.03 \text { years }\end{array}$ & Age: 8-13 years & 13.66 years \\
\hline $\begin{array}{l}\text { Preva- } \\
\text { lence of } \\
\text { hyperpla- } \\
\text { sia }\end{array}$ & $\begin{array}{c}\text { PHE: } 34.5 \%, \mathrm{VPT}: \\
18 \%, \\
\text { Control } 18 \%\end{array}$ & $\begin{array}{l}\text { PHE: } 15.61 \% \text {, } \\
\text { control: } \\
9.48 \%\end{array}$ & $\begin{array}{l}\text { 35\% patients } \\
\text { taking PHE pre- } \\
\text { sented grade I } \\
\text { hyperplasia as } \\
\text { well as } 10 \% \text { of } \\
\text { those taking } \\
\text { CBZ }\end{array}$ & $\begin{array}{c}38.9 \% \text { no gingival } \\
\text { hyperplasia asso- } \\
\text { ciated with ATC } \\
\text { use; } 37.04 \% \text { mild } \\
\text { gingival hyper- } \\
\text { plasia; } 24.07 \% \\
\text { severe gingival } \\
\text { hyperplasia }\end{array}$ & $\begin{array}{l}57 \% \text { patients } \\
\text { taking PHE } \\
\text { only and } \\
31 \% \text { patients } \\
\text { associating } \\
\text { co-medica- } \\
\text { tion to PHE }\end{array}$ & $\begin{array}{l}\text { PHE: } 62 \% \\
\text { grade land } 8 \% \\
\text { grade } 0\end{array}$ & $\begin{array}{l}\text { PHE: vertical index } \\
73 \% ; \text {;nnPHE: } \\
\text { vertical index } 31.8 \% \text {; } \\
\text { control: vertical } \\
\text { index } 1 \%\end{array}$ & PHE:56.7\% & $\begin{array}{l}\text { PHE: } 53.3 \% ; \\
\text { VPT: } 6.66 \% ; \\
\text { CBZ:0\% }\end{array}$ \\
\hline $\begin{array}{l}\text { Evaluation } \\
\text { time }\end{array}$ & Cross-sectional & $\begin{array}{l}\text { Cross-sec- } \\
\text { tional }\end{array}$ & cross-sectional & cross-sectional & $\begin{array}{l}\text { cross-sec- } \\
\text { tional }\end{array}$ & $\begin{array}{l}\text { cross-sectional } \\
\text { and retrospec- } \\
\text { tive }\end{array}$ & cross-sectional & $\begin{array}{l}\text { 6-month pros- } \\
\text { pective }\end{array}$ & $\begin{array}{l}\text { 6-month } \\
\text { prospective }\end{array}$ \\
\hline Location & $\begin{array}{l}\text { Newcastle, } \\
\text { England }\end{array}$ & $\begin{array}{l}\text { Newcastle, } \\
\text { England }\end{array}$ & $\begin{array}{l}\text { Huddinge, } \\
\text { Sweden }\end{array}$ & $\begin{array}{l}\text { Prague, Chec } \\
\text { Republic }\end{array}$ & $\begin{array}{l}\text { Newcastle, } \\
\text { England }\end{array}$ & $\begin{array}{l}\text { Durban, South } \\
\text { Africa }\end{array}$ & Terraca, Barcelona & $\begin{array}{l}\text { Chandigarh, } \\
\text { India }\end{array}$ & Ludhiana, Indi \\
\hline $\begin{array}{l}\text { Probing } \\
\text { Depth }\end{array}$ & $\begin{array}{c}\text { Pockets bigger } \\
\text { than 3mm:PHE } \\
4,5 \% \text {, VS } \\
31.6 \% \text {, Control } \\
21 \%\end{array}$ & $\begin{array}{l}\text { PHE: } 18.91 \\
\text { sites with } \\
\text { PD>3mm, } \\
\text { Control: } 12.57 \\
\text { sites with } \\
\text { PD>3mm }\end{array}$ & $\begin{array}{l}\mathrm{PD}>4 \mathrm{~mm} \text { more } \\
\text { common in } \\
\text { patients taking } \\
\text { PHE, average } \\
\text { PD of PHE 4.3 } \\
\text { and CBZ } 1.9\end{array}$ & not assessed data & $\begin{array}{l}26.74 \%>3 \mathrm{~mm} \\
\text { in PHE; } \\
\text { 17.64\% >3mm } \\
\text { in PHE } \\
\text { UAED }\end{array}$ & $\begin{array}{l}\text { not assessed } \\
\text { data }\end{array}$ & $\begin{array}{c}\text { PD > 3mm: PHE } \\
\text { 30\%, non } \\
\text { PHE 18\%, control } 5 \%\end{array}$ & not assessed data & $\begin{array}{c}\text { PHE: } 3.03 \mathrm{~mm} ; \\
\text { VPT } 2.62 \\
\text { mm; CBZ: } 2.52 \\
\text { mm }\end{array}$ \\
\hline $\begin{array}{l}\text { Index } \\
\text { used to } \\
\text { evaluate } \\
\text { hyperpla- } \\
\text { sia }\end{array}$ & Seymour 1985 & Seymour 1985 & $\begin{array}{l}\text { Angelopoulos } \\
\text { (1975) }\end{array}$ & $\begin{array}{l}\text { Haris and Ewalt } \\
\text { index modified } \\
\text { in } 1942\end{array}$ & Seymour 1985 & Author's index & $\begin{array}{l}\text { Angelopoulos and } \\
\text { Goaz, modified by } \\
\text { Miller and Damm; } \\
\text { Seymour modified } \\
\text { by Miranda }\end{array}$ & $\begin{array}{l}\text { Haris and Ewalt } \\
\text { index modified } \\
\text { in } 1942\end{array}$ & $\begin{array}{l}\text { Haris and Ewalt } \\
\text { index modified } \\
\text { in } 1942\end{array}$ \\
\hline
\end{tabular}

Legend: ATC: anticonvulsants, CBZ: carbamazepine, ETX: ethosuximide, GH: gingival hyperplasia, PD: probing depth, PHE: phenytoin, PMD: primidone, PB: phenobarbital, VPT: sodium valproate. 


\section{DISCUSSION}

Anticonvulsants were first used in 1938, with the discovery of PHE. This drug has been used in the treatment of epilepsy, bipolar disorder, cerebral palsy, neuropathic pain, among other neurological alterations, as well as for the treatment of ventricular arrhythmias [22]. $\mathrm{GH}$ is one of the side effects of anticonvulsant drugs. Studies show the incidence of this gingival alteration, which can cause esthetic and functional issues in patients [2-5,10-12, 23].

In the analysis of the results obtained in the literature, it is possible to notice that the great majority of studies presented incidence of $\mathrm{GH}$ associated with anticonvulsant use. Nevertheless, there is a report on the nonincidence of this undesirable effect in children using CBZ [14]. The greatest incidence (varying from $15.61 \%$ to $73 \%$ ) of GH was associated with the use of PHE. Regarding the methodological quality of the studies, the results showed that all the included studies (comparative and noncomparative) presented a low risk of bias (good quality).

GH associated with PHE presents a clearly fibrotic clinical characteristic. On the other hand, GH caused by other classes of drugs, such as cyclosporine, is associated with a discrete fibrosis aspect and intense inflammation [24]. The anticonvulsant action mechanism associated with GH is still unknown. Studies point to a multifactorial character for the development of this gingival alteration, where genetic susceptibility is a determining factor. It is likely that there is stimulation in the proliferation of some populations of gingival fibroblasts, which somehow would justify individual susceptibility to these drugs [21]. In addition, some studies show that due to an imbalance between synthesis and degradation of extracellular matrix (ECM), an accumulation of collagen fibers may occur, when reduction of the collagen degradation is more likely than its production increase [2527]. This gingival increase can be related to an increased production of the transforming growth factor beta (TGF- $\beta$ ) and connective tissue growth factor (CCN2 growth factor), which leads to greater synthesis and deposition of extracellular matrix. Besides overexpression of these molecules, there is an increase in the proliferation of mesenchymal cells and decreased apoptosis [24].

GH induced by anticonvulsant use impairs oral hygiene. This condition, associated with the fact that a great number of these patients are incapable of carrying out their oral hygiene, due to muscle weakness, aggravates bacterial buildup and plaque formation. Taken together, it is plausible to affirm that anticonvulsant use exacerbates inflammation and gingival hyperplasia $[23,24]$. Studies point to a controversy regarding the role of bacterial buildup and plaque as a contributing factor for the development of $\mathrm{GH}$ or a consequence of it [28], being classified by some authors as a risk factor $[19,21]$ or not [14].

Despite not causing significant damage to the health of a patient, this fibrotic increase directly affects quality of life, and may indirectly lead to systemic negative effects [29-31].

One option for GH treatment is to change the medication according to prescription from a neurologist and adopt a conservative periodontal treatment, emphasizing daily oral hygiene. In cases of no GH improvement within 6 to 12 months, periodontal surgery can be carried out to increase the clinical crown, using gingivectomy/gingivoplasty, the most frequently employed technique, which can be performed by laser or conventionally. Many times, further surgeries are necessary to control recurrent GH $[3,4,32,33]$.

The use of folic acid has been associated with the use of anticonvulsant as an adjuvant to reduce GH development. However, studies point that the association between folic acid and PHE use does not inhibit GH development, but delays it $[34,35]$. 
The prevalence of $\mathrm{GH}$ varied widely between studies, mainly regarding the anticonvulsants used. Several studies evaluated the prevalence of GH associated with PHE and its association with other anticonvulsants $[6,10,13$ $15,20]$. When PHE is associated with another anticonvulsant, a reduction varying from $18 \%$ to $26 \%$ can be observed in GH incidence $[10,15]$.

CBZ is considered the safest anticonvulsant for children, given that its use has not been associated with GH development [14,36]. However, PHE treatment is also used in children who present GH development after 6 months of therapy with this medication [7]. Studies show a correlation between the presence of dental plaque, as a risk factor and aggravating circumstance for GH $[19,21]$. Conversely, another study demonstrated that gingival inflammation is a risk factor for GH development [5]. Probing depth greater than $3 \mathrm{~mm}$ is considered statistically significant for evaluation of the correlation with GH [14,21]. This probing depth increase can be associated with the fact that GH leads gingival edge to more coronary levels, which tends to increase probing depth, even when there is no clinical attachment loss.

Regarding sex and race characteristics, anticonvulsants present similar GH development tendencies $[10,13,15]$. However, a study pointed to a $33.4 \%$ higher incidence of severe $\mathrm{GH}$ in men than in women [20]. GH can be severe due to the age factor, since PHE is used in a wide age group and very often the individual initiates its use during childhood, extending it throughout life. Thus, the incidence among age groups is varied.

It is possible to notice a greater severity of GH associated with PHE use, when drug concentration did not present itself as a risk factor for its development and severity [5]. The associated use of PHE with other anticonvulsants tends to reduce the extension of $\mathrm{GH}$; however, it does not hinder its development [10]. In addition, severe GH associated with anticonvulsants was found in children [20,34].
Recent studies revealed higher production of prostaglandin E2 (PGE2), transforming growth factor-beta (TGF- $\beta$ ) and interleukin-6 (IL-6) in the gingival fibroblasts of children exposed to PHE, when compared with that of adults $[37,38]$, while there was a reduction in interleukin-8 (IL8) production [38].

The limitations of this review were only related to the implementation of qualitative analysis, due to the lack of standardization in the presentation of the results. Given the fact that several methods were used to evaluate gingival growth and plaque index, there is a considerable reduction in the comparative data available about epidemiological information on the actual severity of the disease [21]. The studies selected were not in most randomized clinical trials (RCT), due to the absence in the literature on the subject [18]. Thus, it is suggested that RCT studies should be made with the standardization of data collection.

\section{CONCLUSION}

It was concluded that among commonly used anticonvulsants, PHE is the drug with higher incidence of $\mathrm{GH}$, varying from $15.61 \%$ to $73 \%$. However, further studies aiming at understanding the action mechanism of anticonvulsants that induce GH are needed. In addition, GH prevention methods are necessary, since this gingival alteration is a significant side effect, which is aggravated by poor oral hygiene in patients with motor deficits.

\section{Conflict of interest}

The authors have no proprietary, financial, or other personal interest of any nature or kind in any product, service, and/or company that is presented in this article.

\section{REFERENCES}

1. Priyadharshini V, Belure VV, Triveni MG, Tarun Kumar AB, Mehta DS. Successful management of phenytoin and phenobarbitone induced gingival enlargement: A multimodal approach. Contemp Clin Dent. 2014 Apr;5(2):268-71. doi: 10.4103/0976-237X.132365 
2. Dhingra K, Prakash S. Gingival overgrowth in partially edentulous ridges in an elderly female patient with epilepsy: a case report. Gerodontology. 2012 Jun;29(2):e1201-6. doi: 10.1111/j.1741-2358.2012.00624.x

3. Luvizuto ER, da Silva JB, Campos N, Luvizuto GC, Poi WR, Panzarini SR. Functional aesthetic treatment of patient with phenytoin-induced gingival overgrowth. J Craniofac Surg.2012 May;23(3):e174-6. doi: 10.1097/ SCS.0b013e31824de16e

4. Nakib N, Ashrafi SS. Drug-induced gingival overgrowth. Dis Mon. 2011;57(4):225-30. doi:10.1016/j.disamonth.2011.03.010

5. Brunet L, Miranda J, Roset P,Berini L, Farré M, Mendieta C. Prevalence and risk of gingival enlargement in patients treated with anticonvulsant drugs. Eur J Clin Invest. 2001;31(9):781-8. doi:10.1046/.1365-2362.2001.00869x x

6. Mani KS, Rangan G, Srinivas HV, Srindharan VS, Subbakrishna DK. Epilepsy control with phenobarbital or phenytoin in rural south India: the Yelandur study. Lancet. 2001 Apr 28;357(9265):1316-20. doi:101016/s01406736(00)04516-5

7. Prasad VN, Chawla HS, Goyal A, Gauba K, Singhi P. Folic acid and phenytoin induced gingival overgrowth-is there a preventive effect. J Indian Soc Pedod Prev Dent. 2004 Jun;22(2):82-91.

8. Kimball RF. A delayed change of phenotype following a change of genotype in paramecium aurelia. Genetics. 1939 Jan;24(1):49-58.

9. Ghafoor PA, Rafeeq M, Dubey A. Assessment of oral side effects of Antiepileptic drugs and traumatic oro-facial injuries encountered in Epileptic children. J Int Oral Health. 2014 Apr;6(2):126-8.

10. Kamali F,McLaughlin WS, Ball DE, Seymour RA. The effect of multiple anticonvulsant therapy on the expression of phenytoin-induced gingival overgrowth. J Clin Periodontol.1999 Dec;26(12):802-5. doi:10.1111/.1600051x.1999.tb02523.x

11. Marakoglu I, Gursoy UK, Cakmak H, Marakoglu K. Phenytoin-induced gingival overgrowth in un-cooperated epilepsy patients. Yonsei Med J. 2004;45(2):337-40. doi:10.3349/ymj.2004.45.2.337

12. Chacko $L N$, Abraham S. Phenytoin-induced gingival enlargement. BMJ Case Rep. 2014 May 28; 2014. doi: 10.1136/bcr-2014-204670

13. Dahllöf G,Preber H, Eliasson S, Rydén H, Karsten J, Modéer T. Periodontal condition of epileptic adults treated long-term with phenytoin or carbamazepine. Epilepsia. 1993 Sep-0ct;34(5):960-4. doi:10.1111//.15281157.1993.tb02118.x

14. Suneja B, Chopra S, Thomas AM, Pandian J. A Clinical Evaluation of Gingival Overgrowth in Children on Antiepileptic Drug Therapy. J Clin Diagn Res. 2016;10(1):ZC32-ZC36. doi:10.7860/JCDR/2016/16443.7069

15. Seymour RA, Ellis JS, Thomason JM. Risk factors for drug-induced gingival overgrowth. J Clin Periodontol. 2000;27(4):217-23. doi:10.1034/j.1600051x.2000.027004217.x

16. Katz J, Givol N, Chaushu G, Taicher S, Shemer J. Vigabatrin-induced gingival overgrowth. J Clin Periodontol. 1997;24(3):180-2. doi:10.1111/.1600-051x.1997. tb00488.x

17. Moher D, Liberati A, Tetzlaff J, Altman DG. Preferred reporting items for systematic reviews and meta-analyses: the PRISMA statement. Int J Surg. 2010;8(5):336-41. doi: 10.1016/j.jisu.2010.02.007

18. Slim K, Nini E, Forestier D, Kwiatkowski F, Panis Y, Chipponi J. Methodologica index for non-randomized studies (minors): development and validation of a new instrument. ANZ J Surg. 2003 Sep;73(9):712-6. doi:10.1046/j.14452197.2003.02748.x
19. Majola MP,McFadyen ML, Connolly C, Nair YP, Govender M, Laher MHE. Factors influencing phenytoin-induced gingival enlargement. J Clin Periodontol. 2000 Jul; 27(7):506-12. doi:10.1034/j.1600051x.2000.027007506.x

20. Perlík F, Kolínová M,Zvárová J, Patzelová V. Phenytoin as a risk factor in gingival hyperplasia. Ther Drug Monit. 1995 0ct;17(5):445-8. doi:10.1097/00007691-199510000-00002

21. Thomason JM, Seymour RA, Rawlins MD. Incidence and severity of phenytoin-induced gingival overgrowth in epileptic patients in general medical practice. Community Dent Oral Epidemiol. 1992 0ct;20(5):288-91. doi:10.1111/j.1600-0528.1992.tb01701.x

22. Rang HP. Rang \& Dale farmacologia. 7.ed. Rio de Janeiro: Elsevier; 2012.

23. Guaré RO, Franco VB. Hiperplasia gengival em crianças: uso de anticonvulsivantes e higiene oral. Rev Odontol Univ São Paulo. 1998 Jan./ Mar;:2(1):39-45.

24. Trackman PC, Kantarci A. Connective tissue metabolism and gingival overgrowth. Crit Rev Oral Biol Med. 2004 Jun 4;15(3):165-75. doi:10.1177/154411130401500305

25. Salo T, Oikarinen KS, Oikarinen Al. Effect of phenytoin and nifedipine on collagen gene expression in human gingival fibroblasts. J Oral Pathol Med. 1990 0ct;19(9):404-7.

26. Kato T, Okahashi N, Kawai S, Kato T, Inaga H, Morisaki I, Amano A. Impaired degradation of matrix collagen in human gingival fibroblasts bythe antiepileptic drug phenytoin. J Periodontol. 2005 Jun;76(6):941-50.

27. Kanno CM, Oliveira JA, Garcia JF, Castro AL, Crivelini MM. J Periodontol. 2008 Jan;79(1):114-22.

28. Seymour RA, Thomason JM, Ellis JS. The pathogenesis of drug-induced gingival overgrowth. J Clin Periodontol. 1996 Mar;23(3 Pt 1):165-75.

29. Bharti V,Bansal C. Drug-induced gingival overgrowth: The nemesis of gingiva unravelled. J Indian Soc Periodontol. 2013; Mar- Apr; 17(2):182-7. doi: 10.4103/0972-124X.113066

30. Seymour RA, Smith DG, Turnbull DN. The effects of phenytoin and sodium valproate on the periodontal health of adult epileptic patients. J Clin Periodontol. $1985 \mathrm{Jul} ; 12(6): 413-9$

31. Trackman PC, Kantarci A. Molecular and clinical aspects of druginduced gingival overgrowth. J Dent Res. 2015 Apr;94(4):540-6. doi: $10.1177 / 0022034515571265$

32. Devi PK, Kumar GP,Bai YD, Ammaji AD. Ipsilateral idiopathic gingival enlargement and it's management using conventional gingivectomy and diode laser: Are current case after 15 years. J Indian Soc Periodontol. 2013 Jul;17(3):387-90. doi: 10.4103/0972-124x.115649

33. Mavrogiannis M, Ellis JS, Seymour RA, Thomason JM. The efficacy of three different surgical techniques in the management of drug-induced gingival overgrowth. J Clin Periodontol. 2006 Sep;33(9):677-82. doi:10.1111//.1600051X.2006.00968.x

34. Prasad VN, Chawla HS, Goyal A, Gauba K, Singhi P. Incidence of phenytoin induced gingival overgrowth in epileptic children: a six month evaluation. J Indian Soc Pedod Prev Dent. 2002 Jun;20(2):73-80.

35. Brown RS, Di Stanislao PT, Beaver WT, Bottomley WK. The administration of folic acid to institutionalized epileptic adults with phenytoin-induced gingival hyperplasia. a double-blind, randomized, placebo-controlled, parallel study. Oral Surg Oral Med Oral Pathol. 1991 May;71(5):565-8. doi:10.1016/00304220(91)90363-h 
36. Lundstrom A, Eeg-Olofsson 0, Hamp SE. Effects of epileptic drug treatment with carbamazepine or phenytoin on the oral state of children and adolescentes. J CLin Periodontol 1982 Dec; 9:482-8. doi: 10.1111//.1600051X.1982.tb02109.x

37. Nazemisalman B, Vahabi S, Bandehpour M, Aryankia AK. Phenytoin effects on inflammatory mediator's production by gingival fibroblasts: a comparative study in children and adults. Oral Health Dent Manag. 2014 Sep;13(3):847-53.
38. Vahabi S, Moslemi M, Nazemisalman B, YadegariZ. Phenytoin effects on proliferation and induction of IL $1 \beta$ and PGE2 in pediatric and adults' gingival fibroblasts. Open J Stomatol. 2014 Sep; 4, 452-62. doi: 10.4236/ ojst.2014.49061

\section{Leticia Helena Theodoro}

(Corresponding address)

Dental Assistance Center for Disabled Persons (CAOE)

São Paulo State University (UNESP), School of Dentistry, Araçatuba

Rodovia Marechal Rondon km 527/528, Araçatuba, SP, Brazil

Date submitted: 2020 Mar 27

Email: leticia.theodoro@unesp.br 